\title{
Increased Awareness of Teenagers / Young Mothers in Prevention Breast Cancer Through Realize in Public in Kenagarian Lubuk Alung District of Lubuk Alung Padang Pariaman
}

\author{
Maidawilis $^{1 *}$ and Mike Asmaria ${ }^{2}$
}

\author{
${ }^{1}$ Faculty of Sports Sciences, Universitas Negeri Padang, Padang, Indonesia \\ ${ }^{2}$ Dep. Health and Recreation, Faculty of Sports Sciences, Universitas Negeri Padang \\ *Corresponding author. Email: maidawilis@fik.unp.ac.id;
}

\begin{abstract}
Early detection of breast cancer is a regular and systematic effort or way of breast examination performed by the woman itself which is an integral part of screening program or early detection (Endang, 2014). The lack of knowledge and community skills about breast examination itself so that the case of breast cancer occurs increase, the society in the Kenagarian Lubuk Alung rarely and never even get training on breast examination Own. To solve the problem is considered important to increase Awareness of teenagers / mothers in the prevention of Ca Mamae through realizing in the Kenagarian Lubuk Alung. In order for training to achieve optimal results is required involving partners with the partner Kenagarian Lubuk Alung, Lubuk Alung District. The method of approach in solving the partner's problem is as a direct discussion with the community, training on the practice of Chest Examination (realize) in teenagers and young mothers. The activities are held in July to October in the village Mushala Koto Buruk Kenagarian Lubuk Alung and followed by participants on average 15 up to 20 people. The results of this training and the young mothers in the Kenagarian Lubuk Alung can already do early detection Ca Mamae with his own chest examination (realizing) and the prevention, that has been formed cadre as a mentor of CA Mamae as many as two people from the village Koto Buruk Kenagarian Lubuk Alung. Expected teenagers and young mothers of the village Koto Buruk Kenagarian Lubuk Alung can do the prevention of Ca Mamae early by avoiding the trigger factor and consuming healthy food for breast health.
\end{abstract}

Keywords: Ca mammae, Breast Self Exam

\section{INTRODUCTION}

Cancer Breast is is a disease in which occurs the growth of excessive or development is not controlled from the cells (tissue) breast, This is happen to women as well as men. From all over the corners of the world, the disease cancer breast (Breast Cancer / Carcinoma mammae) reported as one of the disease of cancer that caused the death of a number of five (5) beside of cancer of lung, cancer of the uterus, cancer of liver and intestine cancer (Nina, 2013). Detection of early cancer of breast is a business or a way of examination the breast is regularly and systematically carried out by the woman 's own which is a part is not separated from screening or detection of early (Endang, 2014 ).

Life style and habit day-to-day has changed the society habit which triggers the occurrence of $\mathrm{Ca}$ breast, the problems which are likely the same, namely:
1) Tend to be low community knowledge about chest examination itself

2) Tend to be low public knowledge about the practice of chest examination itself.

3) Community has never received a breast examination training itself.

Occurrence of Increased Knowledge Society Especially Teens Young mother in Prevention Ca mammary with "SADARI" or "Breast Self Exam / BSE" method.

\section{METHODS}

The method of approach in solving the partner's problem is as a direct discussion with the community, training on the practice of Chest Examination (realize) in teenagers and young mothers. The activities are held in July to October in the village of Mushala Koto Buruk 
Kenagarian Lubuk Alung and followed by participants on 15 up to 20 peoples.

\section{DISCUSSION}

\section{A. Discussion}

Implementation of activities devoted to the public at Kenagarian Lubuk Alung District of Lubuk Alung Padang Pariaman is intended to help the dissemination to the public, especially for the residents of the koto buruk village on Improving Knowledge of Society Especially Teens / young mother in Prevention Ca mammae with "Sadari" or "Breast Self Exam / BSE" method, because lately have much once the incidence of breast cancer. Stages of activities that run includes the preparation, implementation, monitoring and evaluation, making of reports, and the submission of last reports. Counseling is done by the target primary is the gruop of youth.

Therefore, to solve the problems, then do things as follows:

1) Did the coordinator of regeneration in the field with the device Kenagarian Lubuk Alung District of Lubuk Alung Padang Pariaman, to prepare for the activities that will be implemented.

2) From each of the young mothers and teenagers who are in the village of koto buruak expected to send envoys participants counseling.

3 ) counseling is carried out in mushala village koto buruak and followed by participants an average of 15 up to 20 people

4) The material of counseling arranged by Tim Executive Service To UNP Community which consists of lecturer in the Department of Health Recreation Program Study D III of Nursing

5) The material extension arranged in the form of papers and reproduced in accordance with the number of participants counseling.

6) besides materials and paper form, for demonstrasion and practice.

Tim implementers also provide tools and materials are required to activity counseling are. At the end of the activity is carried out evaluation and given a question and ask redemonstrasion to know about the responses of each participant towards implementing dedication to the community that made by the team Executive Service of the University of Negeri Padang.

\section{CONCLUSION}

Activity dedication to the community carried out by a team of FIK University Negeri Padang in early August
2019. Prevention socialization breast cancer, this is one of the ways to prevent the occurrence of breast cancer so it is expected to be a step early to prevent behavioral of bad life style and repairing conditions of the bad environment, as well as to prevent the risk of the occurrence of breast cancer which can lead to death Some of the factors supporting the activities are among others participant socialization to own volition are great for getting information and knowledge regarding the safety of household electronics equipment.

We expect teenagers and young mothers of the village Koto Buruk Kenagarian Lubuk Alung can do the prevention of $\mathrm{Ca}$ Mamae early by avoiding the trigger factor and consuming good and healthy food for breast health.

\section{REFERENCES}

[1] S, Sepriadi and E, Eldawaty.. The Contribution of Hemoglobin Levels to Students' Physical Fitness ACTIVE: Journal of Physical Education, Sport, Health and Recreation, 2019.

[2] World Health Organization (WHO). Global strategy on Diet, Physical activity and Health. 2003. [Online] Available at: http://www.who.int/dietphysicalactivity/media/en/g sfs.

[3] Sharkey, B. J. Kebugaran dan Kesehatan. Cetakan ke dua. Jakarta: PT. Raja Grafindo Persada Devisi Buku Sport. 2011.

[4] Hermawan, L., Subiyono, H. S., \& Rahayu, S Pengaruh Pemberian Asupan Cairan (Air) terhadap Profil Denyut Jantung pada Aktivitas Aerobik. Journal of Sport Sciences and Fitness, I(2), 2012.

[5] Agus, A. and Sepriadi. Manajemen Kebugaran. Padang: Sukabina Press, 2018.

[6] Arikunto, Suharsimi. Prosedur Penelitian Suatu Pendekatan Praktik. Jakarta: Rineka Cipta, 2016.

[7] Weil, R., and Stöppler, M. C. Aerobic Exercise 2015

[8] Aguiar, L. T., Nadeau, S., Britto, R. R., TeixeiraSalmela, L. F., Martins, J. C., and de Morais Faria C. D. C. Effects of aerobic training on physical activity in people with stroke: protocol for a randomized controlled trial. Trials, 19(1), p: 446. 2018.

[9] Almeida, M. B., and Araújo, C. G. S. Effects of aerobic training on heart rate. Revista Brasileira de Medicina do Esporte, 9(2), pp. 113-120, 2003.

[10] Karacan, S. Effects of long-term aerobic exercise on physical fitness and postmenopausal symptoms with menopausal rating scale. Science \& Sports, 25(1), pp. 39-46, 2010.

[11] Fox EL, Bower RW, Foss ML. The Physiological Basic of Physical Education and Athletics. $4^{\text {th }}$ ed. Philadelphia: Sauders College Publishing, 1988. 